Judit Kleiber

University of Pécs*

UKD 811.511.141'367'37

DOI: 10.4312/linguistica.56.1.161-172

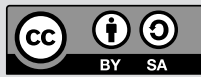

Gábor Alberti

University of Pécs**

Veronika Szabó

University of Pécs ${ }^{* * *}$

\title{
THE INTENSIONAL PROFILES OF FIVE HUNGARIAN IMPERATIVE SENTENCE TYPES ${ }^{1}$
}

\section{INTRODUCTION}

The purpose of the paper is to provide formal pragmatico-semantic analysis for five Hungarian imperative sentence types. Imperatives can be associated with a wide range of speech acts. Our aim is to capture and formalize the information states - beliefs, desires, and intentions - behind the baseline imperative, along with four further types modified by discourse markers or non-standard intonation. The intensional profiles which characterize these five types of Hungarian imperatives are described in the (S)DRT-based discourse-semantic framework of ReALIS.

In the paper, we use the term imperative as a classification of a sentence form type. The two most prominent morphosyntactic features of Hungarian imperatives are reversed verbal prefix (preverb) - verb stem order, and subjunctive morphology. In harmony with Varga (2013), we assume that imperatives, due to their full paradigms, are in the subjunctive mood. The paper investigates five types of imperatives: in addition to the basic type, it analyzes sentences where subjunctive morphology is combined with lengthened intonation, the hortative marker hadd 'let', and the discourse particles csak 'just' and már 'already'.

From the functional perspective, imperatives exhibit great variation, which is recorded by Kaufmann (2012: 14) as the functional inhomogeneity problem. Besides the prototypical command/request interpretation, several possible speaker attitudes can lie behind an imperative sentence, for instance, concession, advice, threatening, asking for or giving permission - some of them are rather far from the meaning of the baseline imperative. Since our aim is to provide pragmatico-semantic analysis, our main interest

* kleiber.judit@pte.hu

** alberti.gabor@pte.hu

*** szabo.veronika@pte.hu

1 The present scientific contribution is dedicated to the 650th anniversary of the foundation of the University of Pécs, Hungary. 
lies in the information states of the interlocutors, primarily the internal world of the speaker (addresser): his/her beliefs, desires and intentions. In the formal interpretation system we apply, it is possible to formalize this information, and then evaluate - through pattern matching between linguistic forms and world models - not only the propositional content of the sentence but also such pragmatic factors as speaker attitude or the sincerity of an utterance.

The paper is organized as follows. Section 2 presents the data: the above mentioned five Hungarian imperative sentence types. The theoretical framework, ReALIS, is introduced briefly in Section 3. Section 4 is devoted to the analysis of the data: the description of the intensional profiles of the baseline imperative, and then the four additional imperative sentence types, which can be regarded as the variants of the basic type fine-tuned by extra elements. Finally, Section 5 draws some conclusions.

\section{THE DATA: FIVE HUNGARIAN IMPERATIVE SENTENCE TYPES}

In this section, we present the data for five types of Hungarian imperatives, starting with the baseline followed by four types modified by extra elements. In Hungarian, an imperative sentence can appear in any person and number; this is the reason why our main (a) examples are all in the general, $3^{\text {rd }}$ person singular form. With almost every type, however, we can point out the most common form, which indicates the preferred agent for the given imperative act (b examples), as well as the least common one with a (strongly) dispreferred agent, (c).

The formal features of the basic type include (i) the shared characteristics of all imperatives: subjunctive morphology and reversed preverb-verb order (if there is a preverb); as well as (ii) standard falling intonation typical for imperatives; and finally (iii) the lack of discourse markers. In the case of the baseline imperative (1), the preferred agent is the addressee (1b), and the dispreferred agent is the addresser (1c). Sentences like (1c) can only appear under special circumstances, for instance, when someone is talking to himself/herself.

(1) a) Költözzön Péter Marihoz! move.Sbjv.3Sg Péter Mari.Ade 'Péter should move to Mari's.'

b) Költözz Marihoz! move.Sbjv.2Sg Mari.Ade 'Move to Mari's!'

c) ${ }^{*}$ Költözzek Marihoz! move.Sbjv.1Sg Mari.Ade

As for their function, even the baseline imperative can express many speaker attitudes. Nevertheless, we can describe the prototypical use of the basic imperative as follows. On the one hand, the addresser (AR) longs for something, typically a change 
in the present state of affairs. On the other hand, he/she expects cooperative behaviour from the addressee (ae). In the preferred $2 \mathrm{sg}$ case (1b), it means that ae should execute the action himself/herself (ae should move to Mari's); while in (1a), AR merely asks ae to have the same intentions as are his/hers (that Péter should move to Mari's). The general 3 sg case constitutes a non-addressee-oriented directive (Péteri 2012) where ae plays a mediating, supporting or tolerating role.

Let us see the first variation of the basic type: an imperative sentence where the first syllable of the verb is unusually lengthened (2).

(2) a) Köööltözzön Péter Marihoz! move.Sbjv.3Sg Péter Mari.Ade 'Fine, Péter can move to Mari's, I do not mind (anymore).'

b) Köööltözz Marihoz! move.Sbjv.2Sg Mari.Ade 'Fine, you can move to Mari's, I do not mind (anymore).'

c) ${ }^{* ?}$ Köööltözzek Marihoz! move.Sbjv.1Sg Mari.Ade

The effect is that now it is not AR who longs for the given action (he/she is rather against its coming true), but someone else: typically ae, or perhaps the Agent of the action (Ag). AR's intentions are somewhat neutral, he/she merely consents to it. The given speech act, thus, expresses concession. Similarly to the baseline imperative, the preferred agent is ae $(2 b)$, while it is excluded that AR, who gives the permission, and Ag, who obtains it, coincide (2c).

The third type contains the hortative marker hadd 'let' (3). Contrary to the previous types, the preferred agent is AR (3b), and the dispreferred agent is ae (3c).

(3) a) Hadd költözzön Péter Marihoz!

let move.Sbjv.3Sg Péter Mari.Ade

'Let Péter move to Mari's.'

b) Hadd költözzek Marihoz!

let move.Sbjv.1Sg Mari.Ade

'Let me move to Mari's.'

c) ${ }^{*}$ Hadd költözz Marihoz!

let move.Sbjv.2Sg Mari.Ade

In harmony with Szücs (2010) and Gärtner-Gyuris (2012), we can establish that, in sentences with subjunctive verb morphology, two main meaning components can be assigned to the Hungarian hortative marker hadd 'let'. The first one can be paraphrased as 'ask for permission', and it can appear with 1st and 3rd person action verb forms $(3 \mathrm{a}-\mathrm{b})$. The second one means 'grant permission', and it only occurs with 3rd-person verbs (3a). In this paper, we only discuss the former usage. With this type, it is ae who is assumed not to long for the move, unlike AR and/or the Agent. In the preferred 1sg 
case (3b), AR conveys his/her own desires; while in the general 3sg case (3a), AR could merely be an "advocate" for Ag (Péter).

The next type of imperative contains the discourse particle csak 'just' (4). As with most types, the preferred agent is ae (4b), and the dispreferred one is AR (4c). This time, however, sentences like (4c) do exist, they merely have a slightly different meaning.

(4) a) Költözzön csak Péter Marihoz! move.Sbjv.3Sg just Péter Mari.Ade

'Let Péter move to Mari's. (Let him try and do that.)'

b) Költözz csak Marihoz! move.Sbjv.2Sg just Mari.Ade

'You should just move to Mari's. (Just try and do that.)'

c) Költözzek csak Marihoz!

move.Sbjv.1Sg just Mari.Ade

'Just wait until I move to Mari's! (You will see what happens.)'

Combined with subjunctive morphology, the particle csak 'just' can express several speaker attitudes: threatening, hastening, encouraging (Fábricz 1986: 78), depending on such contextual factors as intonation and the agent of the action, among others. This paper only discusses the most prominent, "sinister" usage of csak 'just'. With this type, AR is definitely against the move, which is now assumed to be longed for very much by Ag (or, perhaps, by ae). On the surface, AR's intention is neutral, he/she does not want (for ae) to prevent the action. With 2nd-person verb forms (4b), this can be paraphrased as: 'I am tired of persuading you, just do what you want, but you will see ...'. It is very likely, though, that the speaker's intention is, in fact, the exact opposite, and the utterance is a final effort to persuade the interlocutor not to do it ("reversed psychology"). The dispreferred (4c) form also reflects this sinister attitude: AR predicts that this change would be unpleasant for ae (or someone else).

The last discussed type contains the particle már 'already' (5). The preferred agent is ae (5b); while the dispreferred one is AR (5c), occurring only when AR is talking to $\mathrm{him} /$ herself.

(5) a) Költözzön már Péter Marihoz! move.Sbjv.3Sg already Péter Mari.Ade

'I want Péter to decide to move to Mari's at long last.'

b) Költözz már Marihoz!

move.Sbjv.2Sg already Mari.Ade

'Move to Mari's already!'

c) "Költözzek már Marihoz! move.Sbjv.1Sg already Mari.Ade

The particle már 'already' can be associated with a wide range of speaker attitudes in imperative sentences, such as hastening, threatening, encouraging, persuading or 
begging (Fábricz 1986: 188). In its most common usage, it expresses hastening, and the fact that the change would be desirable (Fábricz 1986: 70). In (5a-b), AR thinks that someone, preferably Ag, longs for the move very much, and (hence) wants this person to realize his/her wishes.

This section presented the forms and the primary functions of five Hungarian imperative sentence types and elaborated on their pragmatico-semantic interpretations. The examples have demonstrated that imperatives can be associated with various kinds of distribution of desires and intentions among the three interested participants: the addresser, the addressee and the Agent of the action. In the following two sections, we introduce the framework in which we then provide formal analysis for the discussed imperative sentence types. Our aim is to represent the interlocutors' beliefs, desires and intentions so that the changes in speaker attitudes could be captured by different parameter settings.

\section{THE FRAMEWORK: SOME WORDS ON REALIS}

This section briefly describes the applied theoretical framework ReALIS 'Reciprocal And Lifelong Interpretation System' (Alberti 2011). It would go beyond the scope of this short paper to enumerate arguments for $\Re$ eALIS (the interested reader is referred to Alberti and Kleiber (2012), Alberti (2012), and Alberti and Nöthig (2015)); thus, we only highlight one distinctive property and then provide a short introduction to the formalism.

$\Re$ RALIS can be characterized as a discourse-representation-based (Kamp et al. 2011; Asher and Lascarides 2003) formal semantic theory with a radically new ontology (Alberti and Kleiber 2014). Our starting point is that, in order to account for pragmatic phenomena, we should be able to examine not only the outside world but also the interlocutors' internal worlds (mental states): their beliefs, desires and intentions. The innovative feature of $\Re$ eALIS is that (all) representations are regarded as mental states, which are taken to be part of the world model. Thus, this approach eliminates the "extra level" between the world model and the linguistic form, which is considered to be problematic by the Amsterdam School (e.g., Groenendijk and Stokhof 1991).

The motivation behind founding $\Re$ ReALIS on the basis of this ontology is to create a homogeneous structure for the three representational levels needed to account for linguistic phenomena: the representation of (1) the discourse, (2) the world, and (3) the human mind. In this way, we can decide the truth value of a proposition which exists solely in a person's mind with the same pattern-matching mechanism applied for evaluating utterances referring to the outside world. Due to the fact that all three types of information are represented in the same structure, their formal examination and comparison is possible. For instance, a mismatch between the outside world and the discourse suggests some kind of mistake, while a mismatch between the discourse and the speaker's mind indicates a form of deceit: lie, bluff, white lie, and so on, depending on the parameters of the deviation (Alberti, Vadász and Kleiber 2014).

In ReALIS, it is crucial to differentiate between the addresser/addressee and the speaker/listener roles. The former belongs to the ideal case (cf. Searle 1969), the 
linguistically encoded information of an utterance, while the latter appears in a concrete situation which may not realize the ideal case. For instance, a promise may be insincere, the speaker could be dishonest, the listener may not recognize the irony, and so on. During the interpretation process, it is to be evaluated from clause to clause - in harmony with Oishi's thesis (2014) - whether the speaker is acting legitimately, sincerely, and/or adequately, while, in the on-going discourse, playing the addresser's role and giving the listener the addressee's role. With this approach, when a proposition is evaluated against the current content of the interlocutors' information state, various pragmatic factors can be accounted for, such as the Gricean maxims - e.g., the sincerity or the relevance of an utterance -, irony, politeness, and so on.

In the remainder of the section, we briefly introduce the applied formalism. In ReALIS, a clause performed in an on-going discourse conveys a piece of information which belongs to an intensional profile. For instance, the sentence in (1a) is assigned an intensional profile which characterizes the baseline imperative by representing its pragmatico-semantic contribution: the interlocutors' beliefs, desires and intentions when performing the utterance.

An intensional profile consists of finite components of worldlets. A worldlet encodes one meaning component, such as a desire for an eventuality, or a belief about the intentions of our partner. It can be regarded as a labeled DRS where a level label encodes five essential properties concerning the given piece of information: 1. modality (M): Belief, Desire or Intention; 2. intensity (I) of the modality: some, great, (almost) Maximal, allowing multiple values; 3 . host $(\mathrm{R})$ of the worldlet: primarily AR or ae; 4. time parameter $(\mathrm{T})$; and 5. polarity value $(\mathrm{P}):+($ true),$-($ false), 0 (not specified), also allowing multiple values. The label $\langle\mathrm{B}, \mathrm{M}, \mathrm{AR}, \tau,+\rangle$, for instance, represents that the addresser (AR) knows (Maximally Believes) at time $\tau$ that a given eventuality e holds (+). A worldlet can be embedded in another worldlet which makes it possible to refer to information states. For instance, the series of level labels $\langle\mathrm{B}, \mathrm{M}, \mathrm{AR}, \tau,+\rangle\langle\mathrm{D}, \mathrm{M}, \mathrm{ae}, \tau,+\rangle$ assigned to a worldlet encodes that AR is sure that ae longs for e.

The last discussed feature of ReALIS is that a piece of information can appear in several worldlets simultaneously, which can be understood as a prism effect. When eventuality e is represented in the interlocutor's mind, it is "scattered" like a prism scatters the light (hence the term). The analysis will demonstrate this effect shortly. Thus, an intensional profile is an element of the set $\mathrm{P}\left((\mathrm{M} \times \mathrm{P}(\mathrm{I}) \times \mathrm{R} \times \mathrm{T} \times \mathrm{P}(\mathrm{P}))^{*}\right)$ : the power set of the set of finite sequences of level labels. A clause is interpreted against a worldlet in order to obtain its truth conditions and other semantic and/or pragmatic well-formedness conditions in the given context.

\section{THE ANALYSIS: THE INTENSIONAL PROFILES OF THE DISCUSSED IMPERATIVES}

In this section, we present the intensional profiles of the five types of Hungarian imperatives discussed in Section 2 starting with the baseline imperative ((1a), repeated as (6a)). The eventuality e expressed by (6a), namely Péter's moving to Mari's, appears 
in four different worldlets (prism effect) which are displayed in (6b-e) along with their paraphrases. It is followed by the visual representation of the profile in Figure 1 which is essentially a conglomerate of (S)DRS boxes.

\section{(6) a) Költözzön Péter Marihoz! move.Sbjv.3Sg Péter Mari.Ade 'Péter should move to Mari's.'}

b) $\langle\mathrm{B}, \mathrm{M}, \mathrm{AR}, \tau,-\rangle$ "I (AR) am sure that the result phase $\varphi_{\text {res }}$ (e) of the given eventuality e does not hold (polarity: -) (i.e., Péter and Mari still live in different flats, that is, Péter has not moved to Mari's yet)"

c) $\langle\mathrm{B}, \mathrm{nM}, \mathrm{AR}, \tau,+\rangle\langle\mathrm{B}, \mathrm{M}, \mathrm{ae}, \tau,-\rangle$ "I think that you (ae) are also aware of this fact (the certainty of the assumption is ' $\mathrm{nM}$ '='non-maximal')."

d) $\langle\mathrm{D}, \mathrm{M}, \mathrm{AR}, \tau,+\rangle$ "I long for the aforementioned result phase."

e) $\langle\mathrm{I}, \mathrm{M}, \mathrm{AR}, \tau,+\rangle\left\langle\mathrm{I}, \mathrm{M}, \mathrm{ae}, \tau^{+},+\right\rangle$"I want you to intend the action, too (at a later point $\tau^{+}$in time)."

Figure 1: The intensional profile of the baseline Hungarian imperative sentence type

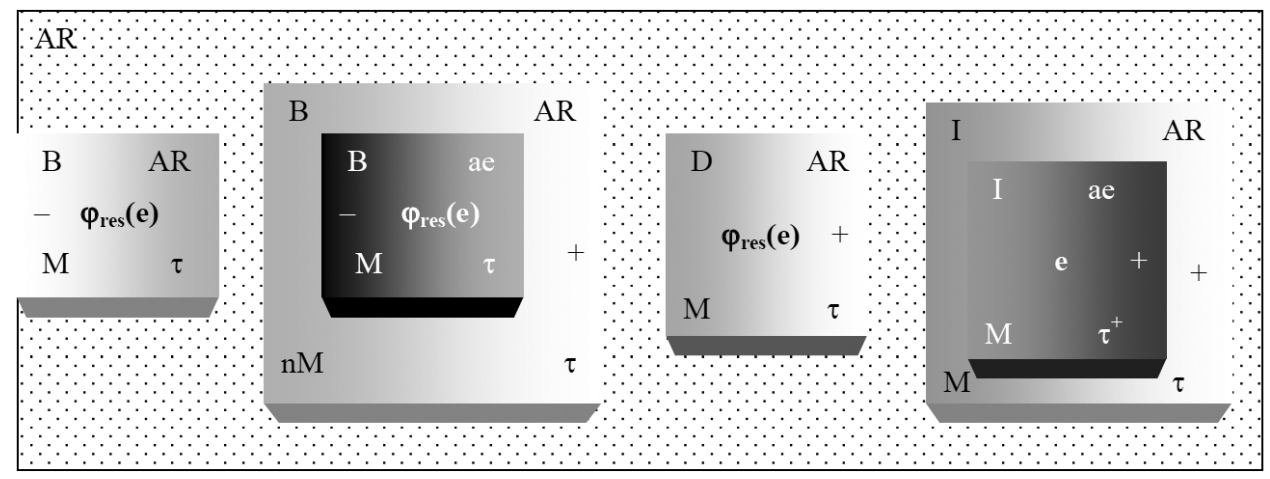

So the intensional profile of the baseline imperative constitutes of four worldlets. The first two worldlets are concerned with AR's beliefs $(6 \mathrm{~b}-\mathrm{c})$; the third worldlet represents AR's desire (6d); and the last worldlet encodes AR's intention (6e). In the prototypical 2sg case ((1b) in Section 2), acting in favour of this intention should lead to ae's executing e him/herself; while in the general 3 sg case (6a), ae is assigned a mediating or supporting role.

Let us now turn to the intensional profiles of the four additional imperative sentence types we discussed in Section 2. The examination reveals that there are rather few parameters which differ from the basic setup - in contrast to the major differences between, for instance, the basic declarative and the basic imperative profiles (Alberti and Kleiber 2014). Thus, we can refer to the four additional types as the variants of the basic type fine-tuned by extra elements. In what follows, we elaborate on the parametric changes responsible for different speaker attitudes associated to imperative types. 
It is common in all types of imperatives that $\mathrm{AR}$ is sure that $\varphi_{\text {res }}(\mathrm{e})$ does not hold (Péter has not moved to Mari's yet) and assumes that ae is also aware of this fact. If there is no such shared piece of knowledge, the speaker has illegitimately given the listener the addressee role. ${ }^{2}$ So there is no variation among the different types regarding AR's beliefs.

As for intentions, we have illustrated in Section 2 that basically two types of intention pattern are relevant to imperatives: an active one, when AR actually wants e to happen, and a neutral/passive one, when he/she does not oppose it. The worldlet which encodes the first shade of meaning $\langle\mathrm{I}, \mathrm{M}, \mathrm{AR}, \tau,+\rangle\left\langle\mathrm{I}, \mathrm{M}, \mathrm{ae}, \tau^{+},+\right\rangle$appears in the intensional profile of the basic type (6e) and the one with the particle már 'already' expressing hastening (example (5) in Section 2). Changing the polarity values to negative $\langle\mathrm{I}, \mathrm{M}, \mathrm{AR}, \tau,-\rangle\left\langle\mathrm{I}, \mathrm{M}, \mathrm{ae}, \tau^{+},-\right\rangle$results in the second shade of meaning: AR asks ae not to prevent e (negative intention = prevention; AR's intention is to prevent ae's prevention). This attitude is represented in the other three cases.

Table 1 below provides a comparative overview of the discussed types. The first two rows represent AR's beliefs concerning $\varphi_{\text {res }}(e)$ or ae's knowledge. The third row encodes the relevant desires (to be elaborated on). The fourth row displays AR's intentions we have presently discussed. The last three rows encode additional information about the uses and interpretations of these sentences: preferred and dispreferred agents (discussed in Section 2) as well as the preferred identification for $\mathrm{r}^{*}$ occasionally occurring in the descriptions.

Table 1: A comparison between the intensional profiles of the five Hungarian imperative sentence types discussed in the paper

\begin{tabular}{|c|c|c|c|c|c|}
\hline & a. Basic & b. CVVVC... & c. hadd & d. csak & e. $m a ́ r$ \\
\hline $\begin{array}{l}\text { AR's knowledge } \\
\text { conc. } \varphi_{\text {res }}(\mathrm{e})\end{array}$ & $\langle\mathrm{B}, \mathrm{M}, \mathrm{AR}, \tau,-\rangle$ & $\leftarrow$ & $\leftarrow$ & $\leftarrow$ & $\leftarrow$ \\
\hline $\begin{array}{c}\text { ae's knowledge } \\
\text { conc. } \varphi_{\text {res }}(\mathrm{e}) \\
\text { (acc. to AR) }\end{array}$ & $\begin{array}{c}\langle\mathrm{B}, \mathrm{nM}, \mathrm{AR}, \tau,+\rangle \\
\langle\mathrm{B}, \mathrm{M}, \mathrm{ae}, \tau,-\rangle\end{array}$ & $\leftarrow$ & $\leftarrow$ & $\leftarrow$ & $\leftarrow$ \\
\hline \multirow{3}{*}{$\begin{array}{c}\text { AR's, ae's and/or } \\
\text { Ag's desire conc. } \\
\varphi_{\text {res }}(\mathrm{e})\end{array}$} & \multirow[t]{3}{*}{$\langle\mathrm{D}, \mathrm{M}, \mathrm{AR}, \tau,+\rangle$} & $\langle\mathrm{D}, \mathrm{M}, \mathrm{AR}, \tau, 0-\rangle$ & $\langle\mathrm{D}, \mathrm{M}, \mathrm{AR}, \tau, 0+\rangle$ & $\langle\mathrm{D}, \mathrm{nM}, \mathrm{AR}, \tau,-\rangle$ & $\langle\mathrm{D}, \mathrm{M}, \mathrm{AR}, \tau, 0+\rangle$ \\
\hline & & $\begin{array}{c}\langle\mathrm{B}, \mathrm{nM}, \mathrm{AR}, \tau,+\rangle \\
\left\langle\mathrm{D}, \mathrm{M}, \mathrm{r}^{*}, \tau,+\right\rangle \\
\end{array}$ & $\begin{array}{c}\langle\mathrm{B}, \mathrm{nM}, \mathrm{AR}, \tau,+\rangle \\
\langle\mathrm{D}, \mathrm{M}, \mathrm{ae}, \tau, 0-\rangle \\
\end{array}$ & $\begin{array}{c}\langle\mathrm{B}, \mathrm{nM}, \mathrm{AR}, \tau,+\rangle \\
\left\langle\mathrm{D}, \mathrm{M}, \mathrm{r}^{*}, \tau,+\right\rangle \\
\end{array}$ & $\begin{array}{c}\langle\mathrm{B}, \mathrm{nM}, \mathrm{AR}, \tau,+\rangle \\
\left\langle\mathrm{D}, \mathrm{M}, \mathrm{r}^{*}, \tau,+\right\rangle \\
\end{array}$ \\
\hline & & & $\begin{array}{c}\langle\mathrm{B}, \mathrm{nM}, \mathrm{AR}, \tau,+\rangle \\
\left\langle\mathrm{D}, \mathrm{M}, \mathrm{r}^{*}, \tau,+\right\rangle\end{array}$ & & $\begin{array}{c}\mathrm{D}, \mathrm{M}, \mathrm{AR}, \tau,+\rangle \\
\left\langle\mathrm{I}, \mathrm{M}, \mathrm{r}^{*}, \tau,+\right\rangle\end{array}$ \\
\hline \multirow{2}{*}{$\begin{array}{l}\text { Ar's intention } \\
\text { conc. e and/or } \\
\text { ae's intention }\end{array}$} & \multirow{2}{*}{$\begin{array}{l}\langle\mathrm{I}, \mathrm{M}, \mathrm{AR}, \tau,+\rangle \\
\langle\mathrm{I}, \mathrm{M}, \mathrm{ae}, \tau+,+\rangle\end{array}$} & $\langle\mathrm{I}, \mathrm{sm}, \mathrm{AR}, \tau, 0\rangle$ & \multirow{2}{*}{$\begin{array}{l}\langle\mathrm{I}, \mathrm{M}, \mathrm{AR}, \tau,-\rangle \\
\left\langle\mathrm{I}, \mathrm{M}, \mathrm{ae}, \tau^{+},-\right\rangle\end{array}$} & \multirow{2}{*}{$\begin{array}{c}\langle\mathrm{I}, \mathrm{M}, \mathrm{AR}, \tau, 0-\rangle \\
\left\langle\mathrm{I}, \mathrm{M}, \mathrm{ae}, \tau^{+},-\right\rangle\end{array}$} & \multirow{2}{*}{$\begin{array}{l}\langle\mathrm{I}, \mathrm{M}, \mathrm{AR}, \tau,+\rangle \\
\left\langle\mathrm{I}, \mathrm{M}, \mathrm{ae}, \tau^{+},+\right\rangle \\
\left\langle\mathrm{I}, \mathrm{M}, \mathrm{r}^{*}, \tau^{++},+\right\rangle\end{array}$} \\
\hline & & $\begin{array}{l}\langle\mathrm{I}, \mathrm{M}, \mathrm{AR}, \tau,-\rangle \\
\left\langle\mathrm{I}, \mathrm{M}, \mathrm{ae}, \tau^{+},-\right\rangle\end{array}$ & & & \\
\hline Pref'd.: Ag= & ae & ae & $\mathrm{AR}$ & ae & ae \\
\hline Dispr'd.: Ag $\neq$ & $\mathrm{AR}$ & $\mathrm{AR}$ & ae & $\mathrm{AR}$ & $\mathrm{AR}$ \\
\hline Pref'd.: r $^{*}=$ & & ae $>A g$ & $\mathrm{AR}>\mathrm{Ag}$ & $\mathrm{Ag}>\mathrm{ae}$ & $\mathrm{Ag}>\mathrm{ae}$ \\
\hline
\end{tabular}

2 This is an excellent example of cases when evaluation against a model does not serve the purpose of obtaining a truth value on the basis of the model of the real world but serves the purpose of calculating pragmatic felicity conditions on the basis of the content of the interlocutors' minds. 
Among the imperatives we have examined, desires have exhibited the greatest variation (see the third row in Table 1). Except for the baseline where only AR's - positive - desire is encoded toward $\varphi_{\text {res }}(\mathrm{e}),(6 \mathrm{~d})$, the imperative profiles contain AR's own desires as well as AR's assumptions concerning ae's - or occasionally someone else's (e.g., Ag's) - desires.

First, let us examine the intensional profile of the imperative with the unusually lengthened first syllable (CVVVC..., column b in Table 1) introduced in (2) in Section 2 which was assigned the speech act of concession. It contains two worldlets concerning desires (third row of Table 1): $\langle\mathrm{D}, \mathrm{M}, \mathrm{AR}, \tau, 0-\rangle$ expressing that AR does not long for $\varphi_{\text {res }}(\mathrm{e})\left(0-\right.$ : neutral or opposing stance); and $\langle\mathrm{B}, \mathrm{nM}, \mathrm{AR}, \tau,+\rangle\left\langle\mathrm{D}, \mathrm{M}, \mathrm{r}^{*}, \tau,+\right\rangle$ expressing that AR assumes that a person $r^{*}$ longs for it, where $r^{*}$ preferably coincides with ae or $\mathrm{Ag}$, in this order (last row).

The next type we discussed contained the hortative marker hadd 'let' (3), and it was assigned the speech act of asking for permission. Its intensional profile (column $\mathrm{c}$ in Table 1) encodes that according to AR ae does not long for $\varphi_{\text {res }}(e)(\langle B, n M, A R, \tau,+\rangle$ $\langle\mathrm{D}, \mathrm{M}, \mathrm{ae}, \tau,-\rangle)$, while AR and Ag, who preferably coincide (fifth row), do. The 0 in $\langle\mathrm{D}, \mathrm{M}, \mathrm{AR}, \tau, 0+\rangle$ refers to the case when $\mathrm{r}^{*}=\mathrm{Ag}$ (last row), that is when AR conveys someone else's wishes.

The intensional profile of the "sinister" usage of csak 'just' is displayed in column d in Table 1, expressing some kind of threatening. The polarity value of AR's desire is negative $(\langle\mathrm{D}, \mathrm{nM}, \mathrm{AR}, \tau,-\rangle)$, while $\mathrm{r}^{*}(=\mathrm{Ag}$ or ae) is assumed to have strong positive desire for $\varphi_{\text {res }}(\mathrm{e})$.

Finally, in the last (e) column of Table 1 the intensional profile for the speech act of hastening is presented which is assigned to the imperative type containing the discourse marker már 'already'. It encodes that AR has either positive or neutral desire for $\varphi_{\text {res }}(\mathrm{e})(\langle\mathrm{D}, \mathrm{M}, \mathrm{AR}, \tau, 0+\rangle)$ while believing that $\mathrm{r}^{*}$ (preferably $\left.=\mathrm{Ag}=\mathrm{ae}\right)$ really longs for it. AR also wishes to get $\mathrm{r}^{*}$ (ae) to intend to do e $(\langle\mathrm{D}, \mathrm{M}, \mathrm{AR}, \tau,+\rangle\langle\mathrm{I}, \mathrm{M}, \mathrm{ae}, \tau,+\rangle)$ via helping this person realize his/her wishes. The three-component worldlet in the "Intentions" row becomes the usual two-component one when applied to $\mathrm{r}^{*}=\mathrm{Ag}=\mathrm{ae}$; while in the case of $r^{*}=\mathrm{Ag} \neq \mathrm{ae}$ (3rd-person verb forms) it encodes the function when ae plays a mediating role.

In this section, we have presented the intensional profiles of the five Hungarian imperative sentence types introduced in Section 2. The analysis has demonstrated that changing a few parameters - polarity values for the interlocutors' intentions and/or desires - can account for the different speech acts associated with different types of imperatives.

A possible direction for future research would address the notion of compositionality in order to answer questions like how the intensional profiles of imperatives are derived and what role the discourse markers play in the process. For the time being, ReALIS applies two means for providing compositional analysis: the simple operation of concatenation, on the one hand, which is suitable for deriving the pragmatico-semantic contribution (intensional profiles) of interrogative imperatives (a basic imperative modified by interrogative elements); and the formal operation of semantic blending 
(based on the cognitive linguistic notion), on the other hand, which is capable of mixing partially incompatible meaning components, such as mood and modality (Alberti, Dóla and Kleiber 2014). Furthermore, we need to provide underspecified representations for discourse markers which could then be composed with the baseline imperative profile in order to acquire a compositional analysis.

\section{CONCLUSION}

The paper investigated the pragmatico-semantic contributions of various imperative sentence types in Hungarian. We have examined the baseline imperative which is prototypically used for commanding, along with four additional types modified by extra elements: imperative sentences with an unusually lengthened syllable expressing concession, the hortative marker hadd 'let' expressing permission, the discourse marker csak 'just' expressing some kind of threatening, and the discourse marker már 'already' expressing hastening. We have analyzed these types in the discourse-semantic framework $\Re$ ALIS and provided their intensional profiles which represent the interlocutors' beliefs, desires and intentions in a formal manner.

We have established that basically two types of intention pattern and several distributions of desires - between the addresser, the addressee and the Agent of the action - play a part in capturing the pragmatico-semantic contributions of different types of imperatives associated with different speech acts. The analysis has demonstrated that the different meanings of the variants can be derived from parametric differences.

The advantageous innovation of $\Re$ ALIS can be formulated as follows: checking whether the speaker and the hearer are suitable for serving as the addresser and the addressee of the linguistically defined speech act simply requires a truth-conditional investigation primarily into certain worldlets in the addresser's mind (e.g., what (s)he hypothesizes and longs for, and what (s)he assumes that certain other persons hypothesize and long for). The task boils down to get to the worldlets in which certain polarity values must then be checked.

\section{References}

ALBERTI, Gábor (2011) ReALIS: Interpretálók a világban, világok az interpretálóban [Interpreters in the world, worlds in the interpreter]. Budapest: Akadémiai Kiadó.

ALBERTI, Gábor (2012) "Where are Possible Worlds? II. Pegs, DRSs, Worldlets and Reification.” In: Alberti G. et al. (eds), Vonzásban és változásban. Pécs: Doctoral School of Linguistics at University of Pécs, 308-323.

ALBERTI, Gábor/Mónika DÓLA/Judit KLEIBER (2014) "Mood and modality in Hungarian: Discourse Representation Theory meets Cognitive Linguistics." Argumentum 10, 172-191.

ALBERTI, Gábor/Judit KLEIBER (2012) "Where are Possible Worlds? Arguments for ReALIS." Acta Linguistica Hungarica 59, 3-26. 
ALBERTI, Gábor/Judit KLEIBER (2014) "ReALIS: Discourse Representation with a Radically New Ontology.” In: L. Veselovská/M. Janebová (eds), Complex Visibles Out There. Olomouc Modern Language Series 4. Olomouc: Palacký University, 513-528.

ALBERTI, Gábor/László NÖTHIG (2015) “ReALIS2.1: The Implementation of Generalized Intensional Truth Evaluation and Expositive Speech Acts in On-Going Discourse." International Journal on Advances in Intelligent Systems 8/1\&2, 85-106.

ALBERTI, Gábor/Noémi VADÁSZ/Judit KLEIBER (2014) "Ideal and Deviant Interlocutors in a Formal Interpretation System." In: A. Zuczkowski et al. (eds), The communication of certainty and uncertainty. Amsterdam: Benjamins, 59-78.

ASHER, Nicholas/Alex LASCARIDES (2003) Logics of Conversation. Cambridge: Cambridge Univ. Press.

FÁBRICZ, Károly (1986) Partikulák a magyar és az orosz nyelvben [Particles in Hungarian and Russian]. Kandidátusi értekezés. Szeged.

GÄRTNER, Hans-Martin/Beáta GYURIS (2012) "Pragmatic markers in Hungarian: Some introductory remarks." Acta Linguistica Hungarica 59, 387-426.

GROENENDIJK, Jeroen/Martin STOKHOF (1991) "Dynamic Predicate Logic." Linguistics and Philosophy 14, 39-100.

KAMP, Hans/Joseph van GENABITH/Uwe REYLE (2011) "Discourse Representation Theory." In: D. Gabbay/F. Guenthner (eds), Handbook of Philosophical Logic. Berlin: Springer, 125-394.

KAUFMANN, Magdalena (2012) Interpreting Imperatives. Dordrecht: Springer.

OISHI, Etsuko (2014) "Discursive functions of evidentials and epistemic modals." In:

S. Cantarini et al. (eds), Certainty-uncertainty - and the attitudinal space in between. Amsterdam: Benjamins, 239-262.

PÉTERI, Attila (2012) "The Hungarian Imperative Particle Hadd." Acta Linguistica Hungarica 59, 439-463.

SEARLE, John (1969) Speech Acts. Cambridge: Cambridge University Press.

SZÜCS, Márta (2010) “A hadd problémaköre [The problem of hadd 'let']." LingDok 9, 193-210.

VARGA, Diána (2013) A magyar felszólitó mondatok szerkezete [The structure of Hungarian imperative sentences]. PhD dissertation. Pázmány Péter University.

\section{Summary \\ THE INTENSIONAL PROFILES OF FIVE HUNGARIAN IMPERATIVE SENTENCE TYPES}

The paper investigates Hungarian imperative sentence types from a pragmaticosemantic point of view. In addition to the baseline imperative, it analyzes types with non-standard intonation pattern and/or discourse markers. We apply the (S)DRT-based discourse-semantic framework of $\Re$ ALIS for the examination and representation of 
five form-function pairs. The discussed types are all assigned an intensional profile which encodes the interlocutors' beliefs, desires and intentions (from the addresser's perspective). The analysis derives the different meanings of the variants from parametric differences.

Keywords: discourse marker, discourse representation structure, imperative sentence type, intensionality

\section{Povzetek \\ INTENZIONALNI PROFILI PETIH MADŽARSKIH VELELNIH STAVČNIH TIPOV}

Članek obravnava madžarske velelne stavke $\mathrm{z}$ vidika pragmatike in semantike. Poleg nezaznamovanega velelnika analiziramo tudi tipe velelnikov z nestandardnimi intonacijskimi vzorci in/ali diskurznimi označevalci. Z diskurzno-semantičnim okvirom ReALIS, ki temelji na (S)DRT, raziščemo in predstavimo pet oblikovno-funkcijskih parov. Obravnavanim tipom določimo intenzionalni profil, ki obsega prepričanja, želje in namere sogovornikov ( $\mathrm{z}$ vidika govorca). Analiza na podlagi parametričnih razlik izpelje različne pomene obravnavanih variant.

Ključne besede: diskurzni označevalec, struktura reprezentacije diskurza, velelni stav$\mathrm{ki}$, intenzionalnost 